\title{
Original
}

\section{Resting Energy Expenditure of the Unhealthy Elderly in the "Roken" in Japan}

\author{
Hidemasa Kuwabara ${ }^{1,2}$, Noriko Yamaoka ${ }^{1}$, Junko Oomaki ${ }^{1}$ and Mitsuo Suzuki ${ }^{1}$ \\ 1 The Geriatric Health Services Facility “Roken Ichiyokan”, Jobu Hospital for Respiratory Diseases, 1012-5 Kozakashi-machi, Maebachi, \\ Gunma 371-0122, Japan \\ 2 The Department of Internal Medicine, National Hospital Organization Numata National Hospital, 1551-4 Kamihara-machi, Numata, \\ Gunma 378-0051, Japan
}

\begin{abstract}
Background: To know actual conditions and a balance between food intake and energy expenditure of each of the elderly in the super-aged society is very important.

Aim: To determine the resting energy expenditure (REE) of the elderly residing in the "Roken".

Methods: For Study 1, REEs of 47 elderly people in the Roken were measured. For Study 2, REEs of 22 patients who were admitted to a general hospital were measured.

Results: In Study 1, REE of the elderly people in the Roken ranged from 523 to 1,628 kcal/day/body; the mean value was $909 \pm 239 \mathrm{kcal} /$ day/body (mean $\pm \mathrm{SD}$ ) and $21.6 \pm 4.5 \mathrm{kcal} / \mathrm{kg} / \mathrm{day}$. A discrepancy between REE and dietary energy intake was observed.

In Study 2, REE of patients in the hospital widely ranged from 589 to 2,549 $\mathrm{kcal} / \mathrm{day} / \mathrm{body}$; the mean value was $1391 \pm 459 \mathrm{~kg} /$ day/body (mean $\pm \mathrm{SD})$.

Conclusions: The mean value of REE of the elderly in the Roken was $74 \%$ lower than that of the healthy individuals in previous reports. The observed discrepancy between REE and dietary energy intake suggested the need for improvement in the effective absorption of nutrients from the digestive system, which may be more important than food intake.
\end{abstract}

\begin{tabular}{l} 
Article Information \\
\hline Key words: \\
energy expenditure, \\
energy intake, \\
disabled, \\
frail, \\
$\quad$ geriatric assessment \\
\hline Publication history: \\
Received: July 23, 2015 \\
Revised: August 27,2015 \\
Accepted: September 3, 2015 \\
\hline Corresponding author: \\
Hidemasa Kuwabara \\
Geriatric Health Services Facility “Roken Ichiyokan”, Jobu \\
Hospital for Respiratory Diseases, 1012-5 Kozakashi- \\
machi, Maebashi, Gunma, 371-0122, Japan \\
Tel: + 81-27-269-6667 \\
E-mail: hidekuwabara @ asahi-net.email.ne.jp \\
\hline
\end{tabular}

\section{Introduction}

Currently, there is a need to determine the energy expenditure (EE) of the elderly, particularly in those who are frail or disabled, and there is also a need to identify the optimal resting energy expenditure (REE) for the elderly in the "Roken", which is a geriatric services facility in Japan ${ }^{1,2}$.

The REE is clinically mesured to evaluate the EE better than the basal energy expenditure (BEE) because of the needs of strict measuring contitions for BEE.

The government of Japan has responded to various issues associated with the rapid growth of the aging population by developing various programs that have promoted health care, medical care, and welfare of the elderly, including the Roken. The Roken is a geriatric services facility in Japan that has been mandated to serve as an intermediary facility for hospitals, homes, and nursing homes. The Roken provides new and unique services that include both medical and welfare services for the elderly. The mission of the Roken is to allow a person who requires long-term care to live a long and meaningful life. Its original purpose of improving the user's level of functioning to permit a return home remains in place to date; however, some users are disabled and could not go home.

In Japan, artificial routes of nutrition through the use of a nasogastric tube or percutaneous endoscopic gastrostomy tube are often provided for the elderly. 
The absorptive effectiveness of alimentary therapy appears to widely vary; for example, some individuals gained weight with an intake of $800 \mathrm{kcal} / \mathrm{day}$, whereas others achieved and maintained a constant weight with an intake of 1,600 kcal/day, regardless of having the same low level of daily activity and remaining in bed all day long (unpublished observation).

The ideal or adequate EE or its requirements of individuals have been previously established. ${ }^{3,4}$ However, information on the relationship between EE and energy requirements, particularly the data related to the rapidly-growing aging population, remains been limited.

We therefore examined REE of elderly in the Roken who were unhealthy and were either frail or disabled. This study is designed as a kind of factual survey for the elderly in the Roken for the first time in the super-aged society in Japan.

\section{Methods}

\section{Study 1 involving 47 subjects from the Roken}

REEs were measured in 47 subjects who were receiving long-term care services and who were admitted to the "Roken Ichiyokan"(http://www.maroon.dti. ne.jp/sheep2/top.html). A Roken is a geriatric services facility in Japan that provides care and assistance to elderly persons who are either frail or disabled and who have low physical activity levels. The 47 subjects comprised 38 females and 9 males. Of these patients, 1 was in the 60s, 9 were in their 70s, 21 were in their $80 \mathrm{~s}$, 15 were in their 90s, and 1 was 100 years old. The average age of the study population was $85.2 \pm 7.6$ $($ mean $\pm \mathrm{SD})$ years (range: $66-100$ years).

REE was measured by indirect calorimetry (VMB$005 \mathrm{~N}$ Vine Tokyo, Japan). The measuring methodology is described in detail elsewhere. ${ }^{5-8}$ REE was measured for $3 \mathrm{~min}$ in a stable general condition, recumbent, or semi-recumbent position at room tem-
Table 1 The equation formulae for the blood gas analysis derived from Fick's equation. Calorimetry was determined by calculating the oxygen expenditure as $1 \mathrm{~mL}$ of oxygen $=5$ calories.

$\dot{\mathrm{V}}_{2}(\mathrm{ml} / \mathrm{min})=\mathrm{CO} \times\left(\mathrm{CaO}_{2}-\mathrm{C} \overline{\mathrm{v}} \mathrm{O}_{2}\right) \times 10$

$\mathrm{CaO}_{2}(\mathrm{ml} / \mathrm{dl})=\left(\mathrm{Hb} \times 1.34 \times \mathrm{SaO}_{2} / 100\right)+\left(\mathrm{PaO}_{2} \times 0.0031\right)$

$\mathrm{C}_{\bar{v}} \mathrm{O}_{2}(\mathrm{ml} / \mathrm{dl})=\left(\mathrm{Hb} \times 1.34 \times \mathrm{S}_{\bar{v}} \mathrm{O}_{2} / 100\right)+\left(\mathrm{PaO}_{2} \times 0.0031\right)$

peratures of $23-20^{\circ} \mathrm{C}$, after at least $1 \mathrm{~h}$ postprandially and after $>30$ min of rest

These measurements were conducted after receiving informed consent from the patients themselves or from their guardians.

Study 2 involving an another group of population as a reference or control.

Another group comprised 22 patients, 8 females and 14 males, with ages ranging from 70 to 90 years. Each patient was troubled with some disease, and the patients were non-frail, frail, or disabled. The average age of this group, which was collected from the previous medical records of patients treated between 1993 and 2001 at the general hospital, National Hospital Organization Numata National Hospital, was $77.5 \pm$ 6.0 (mean $\pm \mathrm{SD}$ ) years.

REEs were calculated by Fick's equation (table 1) from the gas analysis from the Swan-Ganz catheterization of the right hearts of subjects who were suspected of having either pulmonary hypertension or pulmonary thromboembolism and were thus admitted to the hospital after providing informed consent. All the patients of this group were unhealthy and comprised individuals who were non-frail, frail, or disabled.

The measureing condition were in a recumbent position after at least $1 \mathrm{~h}$ postprandially and after $>30$ min of rest but unclear in a relaxing state or nervous. We compared REEs of these patients with those from the Roken and used as a references of another population.

The statistical data are expressed as the mean \pm

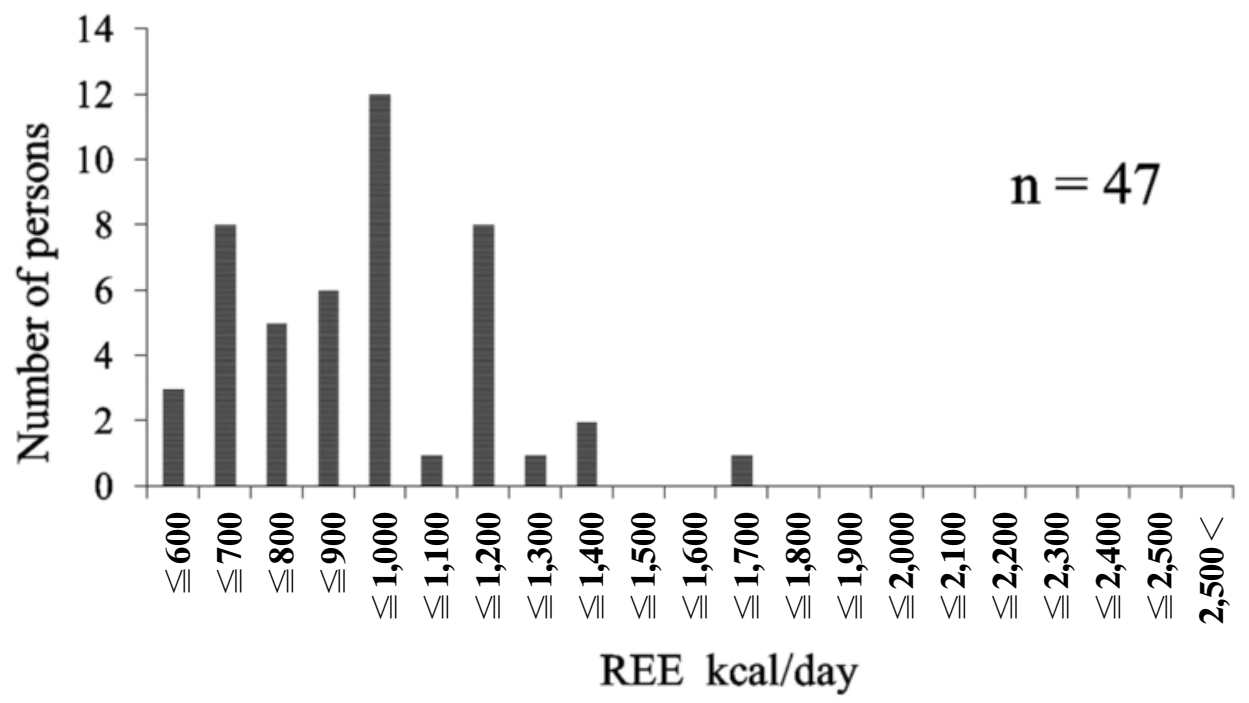

Figure 1 Frequency distribution of REEs of the elderly who resided in the Roken, which showed a normal Gaussian distribution and mean value of $909 \pm 239$ (mean \pm SD) kcal/day/body. All the elderly were unhealthy and were either frail or disabled. 
SD. The linear regression analysis was done by using Microsoft ${ }^{\circledR}$ Exel $^{\circledR} 2010$.

\section{Results}

Study 1

The REE/body of each of the 47 subjects ranged from 623 to $1,628 \mathrm{kcal} / \mathrm{day} /$ body; the mean value was $909 \pm 239$ (mean $\pm \mathrm{SD}) \mathrm{kcal} / \mathrm{day} / \mathrm{body}$ and was $21.6 \pm 4.5 \mathrm{kcal} / \mathrm{kg} /$ day (mean $\pm \mathrm{SD}$ ) (Table 2). Figure 1 shows the frequency distribution of the 47 subjects, which appeared to resemble a normal Gaussian distribution. The correlation coefficient between REE and the degrees of disability ${ }^{9,10}$ was $\mathrm{R}=-0.158$ (Figure 2a) and that between $\mathrm{REE} / \mathrm{kg}$ and the degrees of disability was $\mathrm{R}=-0.01$ (Figure $2 \mathrm{~b}$ ). No relationships were observed among the subjects.

However, as shown in Figure 3, a discrepancy between REE and dietary energy intake (F) was observed. The F/REE ratio of 28 persons without body weight gain nor loss was $1.4 \pm 0.4$ (mean $\pm \mathrm{SD}$ ) (Table 2 ), which indicated that the absorption rate of nutrients widely varied among these individuals.

\section{Study 2}

The REE/body of each of the 22 patients of the reference group ranged from 589 to $2,549 \mathrm{kcal} / \mathrm{day} /$ body; the mean value was $1391 \pm 459 \mathrm{kcal} / \mathrm{day} /$ body (Table 3). The frequency distribution of these patients did not show a normal Gaussian distribution nor

\section{(a)}

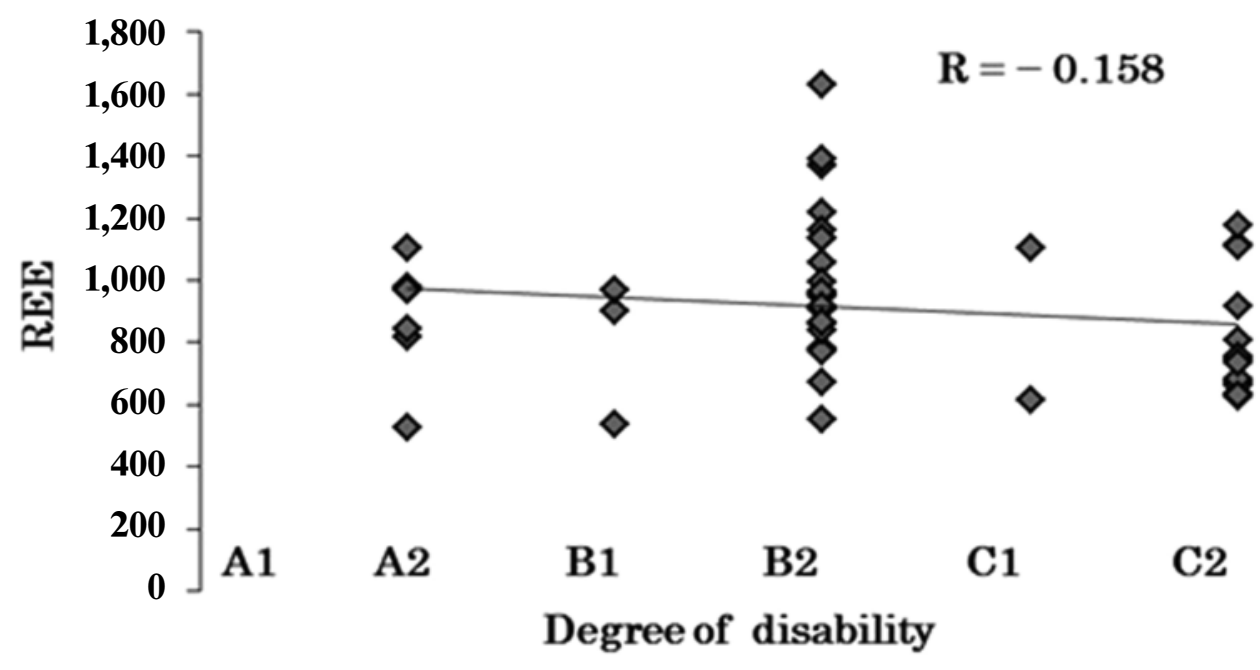

(b)

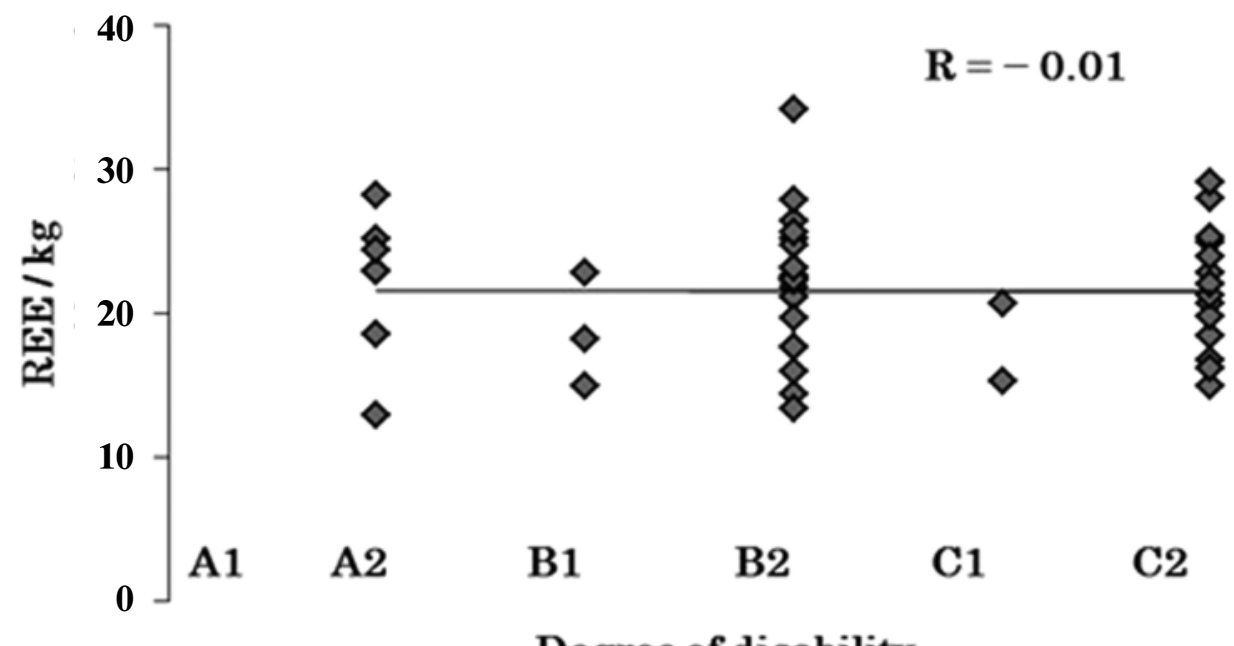

Figure 2 (a) There was no significant correlation between REE and the degree of disability in the Roken. The degree of disability was defined as the gradual deterioration in the condition of daily life from A1 to C2. In A1, the elderly were unable to go outdoors without the aid of an attendant. In $\mathrm{C} 2$, the elderly were bedridden and unable to turn over alone. The evaluation methods of the degree of disability have been described in detail elsewhere. ${ }^{9,10}$

(b) There was no correlation between the REE $/ \mathrm{kg}$ levels and the degree of disability. 


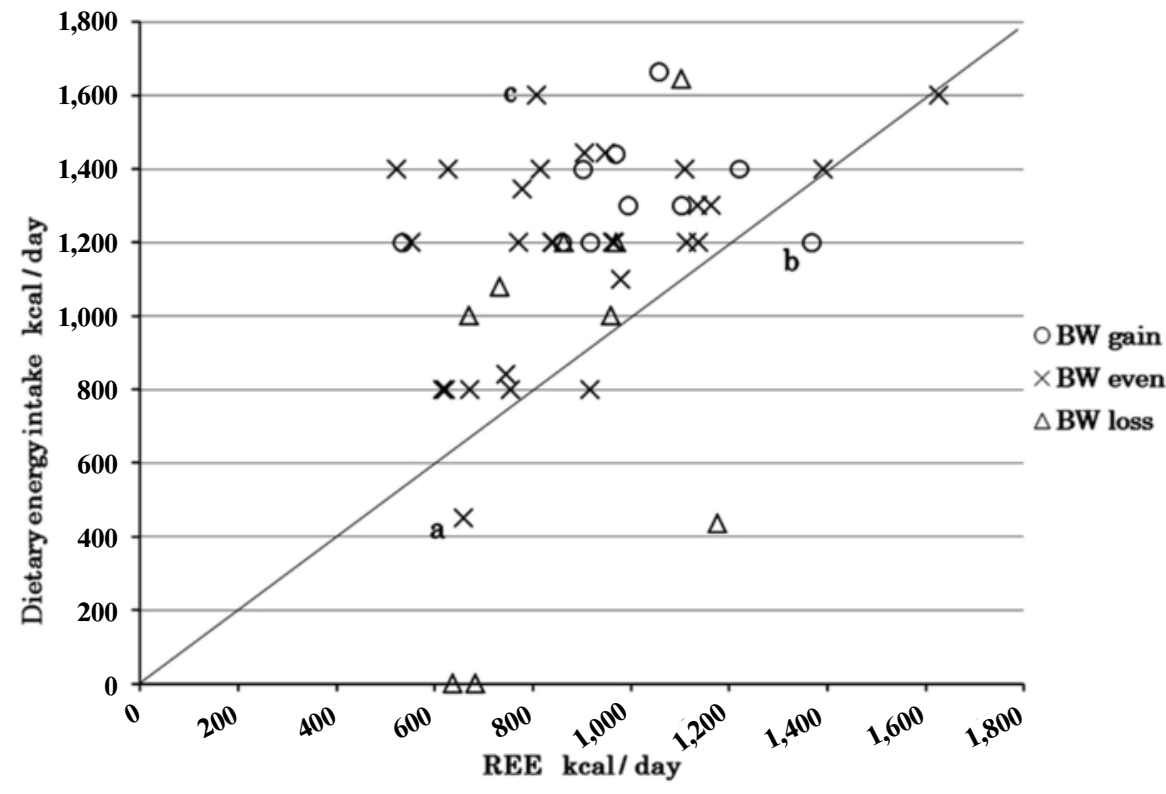

Figure 3 The discrepancy between REE and dietary energy intake; $(\bigcirc)$ indicates body weight gain, $(\times)$ represents body weight being constant, and $(\triangle)$ shows body weight loss. Subjects above the diagonal line showed a dietary energy intake/REE that was greater than 1 .

One subject (a) had systemic edema, whereas another (b) was nervous. The two subjects depicted on the horizontal line were at an end-stage condition and could not eat. One subject (c) had a constant body weight that was maintained for 3 months, regardless of having a dietary intake of 1,600 kcal against REE of $800 \mathrm{kcal}$. Most subjects $(\times)$ were randomly distributed above the diagonal line.

Table 2 Resting energy expenditure (REE) measurements of the elderly in the Roken. REE of the elderly was measured in the Fowler or recumbent position at a resting state for $\geq 30 \mathrm{~min}$ and at least $1 \mathrm{~h}$ postprandially.

\begin{tabular}{|c|c|c|c|c|c|c|c|c|c|c|}
\hline $\begin{array}{l}\text { Case } \\
\text { No. }\end{array}$ & Age & Sex & $\begin{array}{l}\text { Body } \\
\text { height } \\
(\mathrm{cm})\end{array}$ & $\begin{array}{l}\text { Body } \\
\text { weight } \\
\text { (kg) }\end{array}$ & $\begin{array}{l}\text { Degree of } \\
\text { disability }\end{array}$ & $\begin{array}{c}\text { (a) REE } \\
\text { (kcal/day) }\end{array}$ & $\begin{array}{c}\mathrm{REE} / \mathrm{kg} \\
\text { (kcal/kg/day) }\end{array}$ & $\begin{array}{c}\text { Gain/loss of } \\
\text { weight than } \\
\text { 3months before }\end{array}$ & $\begin{array}{l}\text { (b) Actual } \\
\text { food intake } \\
\text { (kcal/day) }\end{array}$ & (b) $/(a)$ \\
\hline 1 & 82 & 우 & 145.0 & 39.1 & A2 & 1,103 & 28.2 & $r$ & 1,300 & 1.2 \\
\hline 2 & 77 & 우 & 153.1 & 49.6 & B1 & 902 & 18.2 & $r$ & 1,400 & 1.6 \\
\hline 3 & 80 & 우 & 136.2 & 38.0 & B2 & 860 & 22.6 & $r$ & 1,200 & 1.4 \\
\hline 4 & 91 & 우 & 154.5 & 38.5 & A2 & 969 & 25.2 & $r$ & 1,440 & 1.5 \\
\hline 5 & 70 & $0^{7}$ & 148.0 & 42.0 & B2 & 1,058 & 25.2 & $r$ & 1,665 & 1.6 \\
\hline 6 & 89 & 우 & 136.0 & 47.0 & B2 & 995 & 21.2 & $r$ & 1,300 & 1.3 \\
\hline 7 & 81 & 우 & 140.0 & 46.2 & B2 & 1,221 & 26.4 & $r$ & 1,400 & 1.1 \\
\hline 8 & 73 & 우 & 145.5 & 43.5 & B2 & 918 & 21.1 & $r$ & 1,200 & 1.3 \\
\hline 9 & 92 & 우 & 149.0 & 53.3 & B2 & 1,369 & 25.7 & $r$ & 1,200 & 0.9 \\
\hline 10 & 88 & 우 & 130.0 & 35.8 & $\mathrm{~B} 1$ & 534 & 14.9 & $r$ & 1,200 & 2.2 \\
\hline 11 & 94 & 우 & 140.8 & 42.7 & A2 & 979 & 22.9 & $\rightarrow$ & 1,100 & 1.1 \\
\hline 12 & 85 & 우 & 147.0 & 43.9 & $\mathrm{~A} 2$ & 815 & 18.6 & $\rightarrow$ & 1,400 & 1.7 \\
\hline 13 & 87 & 우 & 141.3 & 52.1 & B2 & 1,137 & 21.8 & $\rightarrow$ & 1,200 & 1.1 \\
\hline 14 & 66 & 우 & 155.0 & 44.5 & $\mathrm{C} 2$ & 747 & 16.8 & $\rightarrow$ & 840 & 1.1 \\
\hline 15 & 82 & 우 & 143.6 & 42.5 & $\mathrm{~B} 1$ & 968 & 22.8 & $\rightarrow$ & 1,200 & 1.2 \\
\hline 16 & 82 & 우 & 137.7 & 38.3 & B2 & 553 & 14.4 & $\rightarrow$ & 1,200 & 2.2 \\
\hline 17 & 90 & 우 & 140.0 & 40.9 & B2 & 949 & 23.2 & $\rightarrow$ & 1,444 & 1.5 \\
\hline 18 & 86 & 우 & 143.0 & 40.5 & $\mathrm{~A} 2$ & 523 & 12.9 & $\rightarrow$ & 1,400 & 2.7 \\
\hline 19 & 93 & 우 & 145.0 & 44.0 & B2 & 779 & 17.7 & $\rightarrow$ & 1,344 & 1.7 \\
\hline 20 & 74 & 우 & 151.0 & 34.5 & $\mathrm{~A} 2$ & 842 & 24.4 & $\rightarrow$ & 1,200 & 1.4 \\
\hline 21 & 97 & 우 & 143.0 & 36.6 & B2 & 906 & 24.8 & $\rightarrow$ & 1,444 & 1.6 \\
\hline 22 & 78 & 우 & 134.5 & 43.1 & B2 & 964 & 22.4 & $\rightarrow$ & 1,200 & 1.2 \\
\hline 23 & 94 & 우 & 152.0 & 47.7 & B2 & 1,628 & 34.1 & $\rightarrow$ & 1,600 & 1.0 \\
\hline 24 & 82 & 우 & 144.8 & 49.8 & $\mathrm{C} 2$ & 917 & 18.4 & $\rightarrow$ & 800 & 0.9 \\
\hline 25 & 98 & 우 & 126.0 & 40.4 & $\mathrm{C} 1$ & 617 & 15.3 & $\rightarrow$ & 800 & 1.3 \\
\hline
\end{tabular}




\begin{tabular}{|c|c|c|c|c|c|c|c|c|c|c|}
\hline 26 & 86 & 우 & 144.0 & 52.2 & B2 & 1,163 & 22.3 & $\rightarrow$ & 1,300 & 1.1 \\
\hline 27 & 81 & $0^{x}$ & 149.0 & 50.0 & B2 & 1,392 & 27.8 & $\rightarrow$ & 1,400 & 1.0 \\
\hline 28 & 79 & $0^{x}$ & 152.0 & 48.3 & B2 & 772 & 16.0 & $\rightarrow$ & 1,200 & 1.6 \\
\hline 29 & 94 & 우 & 135.4 & 37.5 & B2 & 840 & 22.4 & $\rightarrow$ & 1,200 & 1.4 \\
\hline 30 & 90 & 우 & 140.2 & 32.4 & $\mathrm{C} 2$ & 672 & 20.7 & $\rightarrow$ & 800 & 1.2 \\
\hline 31 & 89 & 우 & 143.0 & 33.4 & $\mathrm{C} 2$ & 660 & 19.8 & $\rightarrow$ & 450 & 0.7 \\
\hline 32 & 83 & $0^{x}$ & 168.5 & 44.7 & $\mathrm{C} 2$ & 1,115 & 24.9 & $\rightarrow$ & 1,200 & 1.1 \\
\hline 33 & 81 & 우 & 145.0 & 39.7 & $\mathrm{C} 2$ & 1,111 & 28.0 & $\rightarrow$ & 1,400 & 1.3 \\
\hline 34 & 100 & 우 & 113.0 & 29.3 & $\mathrm{C} 2$ & 623 & 21.3 & $\rightarrow$ & 800 & 1.3 \\
\hline 35 & 81 & $0^{x}$ & 163.0 & 38.9 & $\mathrm{C} 2$ & 629 & 16.2 & $\rightarrow$ & 1,400 & 2.2 \\
\hline 36 & 85 & $0^{x}$ & 162.0 & 36.6 & $\mathrm{C} 2$ & 808 & 22.1 & $\rightarrow$ & 1,600 & 2.0 \\
\hline 37 & 78 & $0^{x}$ & 153.0 & 49.0 & B2 & 1,137 & 23.2 & $\rightarrow$ & 1,300 & 1.1 \\
\hline 38 & 96 & 우 & 146.0 & 29.9 & $\mathrm{C} 2$ & 755 & 25.3 & $\rightarrow$ & 800 & 1.1 \\
\hline 39 & 90 & 우 & 132.0 & 42.4 & A2 & 971 & 22.9 & $\nu$ & 1,200 & 1.2 \\
\hline 40 & 76 & $0^{7}$ & 156.0 & 53.3 & $\mathrm{Cl}$ & 1,103 & 20.7 & $\nu$ & 1,644 & 1.5 \\
\hline 41 & 78 & 우 & 145.0 & 49.9 & B2 & 670 & 13.4 & $\nu$ & 1,000 & 1.5 \\
\hline 42 & 82 & 우 & 150.2 & 54.4 & B2 & 960 & 17.6 & $\nu$ & 1,000 & 1.0 \\
\hline 43 & 93 & $0^{x}$ & 152.0 & 42.5 & $\mathrm{C} 2$ & 637 & 15.0 & $\nu$ & 0 & 0.0 \\
\hline 44 & 84 & 우 & 148.0 & 43.9 & B2 & 863 & 19.7 & $\nu$ & 1,200 & 1.4 \\
\hline 45 & 90 & 우 & 152.0 & 30.0 & $\mathrm{C} 2$ & 684 & 22.8 & $\nu$ & 0 & 0.0 \\
\hline 46 & 83 & 우 & 145.0 & 40.4 & $\mathrm{C} 2$ & 1,177 & 29.1 & $\nu$ & 435 & 0.4 \\
\hline 47 & 93 & 우 & 144.0 & 30.6 & $\mathrm{C} 2$ & 733 & 24.0 & $\nu$ & 1,080 & 1.5 \\
\hline
\end{tabular}

Table 3 REE of the inpatients of the hospital who were $\geq 70$ years old calculated by Fick's equation when examined by blood gas analysis using the Swan-Ganz right heart catheterization method.

\begin{tabular}{|c|c|c|c|c|c|c|c|c|}
\hline $\begin{array}{l}\text { Case } \\
\text { No. }\end{array}$ & Sex & Age & Disease & $\begin{array}{l}\text { BSA } \\
\left(\mathrm{m}^{2}\right)\end{array}$ & $\begin{array}{c}\text { Date of } \\
\text { examination }\end{array}$ & $\begin{array}{c}\dot{\mathrm{V} O} 2 \\
\mathrm{ml} / \mathrm{m}^{2} / \mathrm{min}\end{array}$ & $\begin{array}{c}\dot{\mathrm{V} O} 2 \\
\mathrm{ml} / \text { body/min }\end{array}$ & $\begin{array}{c}\text { REE } \\
\text { (kcal/day) }\end{array}$ \\
\hline 1 & $0^{7}$ & 70 & COPD + PTE & 1.48 & $12 / 2 / 1993$ & 147 & 217 & 1,562 \\
\hline 2 & $0^{7}$ & 71 & COPD + PTE & 1.27 & $11 / 5 / 1999$ & 279 & 354 & 2,549 \\
\hline 3 & $0^{7}$ & 71 & $\mathrm{CHF}+\mathrm{PH}$ & 1.46 & $1 / 11 / 2000$ & 123 & 180 & 1,296 \\
\hline 4 & 우 & 71 & PTE & 1.33 & $6 / 25 / 1999$ & 104 & 138 & 996 \\
\hline 5 & 우 & 71 & $\mathrm{COPD}+\mathrm{PH}$ & 1.52 & 4/9/1996 & 124 & 189 & 1,357 \\
\hline 6 & $\sigma^{7}$ & 72 & COPD & 1.38 & $11 / 5 / 1992$ & 153 & 211 & 1,519 \\
\hline 7 & $0^{7}$ & 73 & $\mathrm{CHF}+\mathrm{PH}$ & 1.71 & $12 / 7 / 1999$ & 174 & 298 & 2,146 \\
\hline 8 & 우 & 73 & PTE? & 1.36 & $3 / 3 / 1999$ & 130 & 177 & 1,273 \\
\hline 9 & $0^{7}$ & 75 & PTE & 1.71 & $12 / 20 / 1991$ & 151 & 258 & 1,858 \\
\hline 10 & 우 & 75 & $\mathrm{COPD}+\mathrm{PH}$ & 1.1 & $7 / 16 / 1997$ & 120 & 132 & 950 \\
\hline 11 & 우 & 77 & mild $\mathrm{CHF}$ & 1.5 & $3 / 21 / 2000$ & 165 & 248 & 1,782 \\
\hline 12 & $0^{7}$ & 77 & $\mathrm{PH}+\mathrm{ASD}$ & 1.23 & $12 / 15 / 2000$ & 197 & 242 & 1,745 \\
\hline 13 & $0^{7}$ & 79 & PTE & 1.21 & $12 / 14 / 1994$ & 124 & 150 & 1,080 \\
\hline 14 & 우 & 79 & $\mathrm{COPD}+\mathrm{PH}$ & 1.14 & $4 / 19 / 1996$ & 135 & 154 & 1,108 \\
\hline 15 & $0^{7}$ & 79 & $\mathrm{PH} ?$ & 1.45 & $6 / 21 / 1999$ & 76 & 110 & 794 \\
\hline 16 & $0^{7}$ & 79 & $\mathrm{PH} ?$ & 1.45 & $6 / 23 / 1999$ & 111 & 161 & 1,159 \\
\hline 17 & $0^{7}$ & 80 & PTE? & 1.42 & 4/14/1999 & 163 & 232 & 1,667 \\
\hline 18 & $\sigma^{7}$ & 83 & $\mathrm{CHF}+\mathrm{PH}$ & 1.3 & $10 / 20 / 2000$ & 125 & 163 & 1,171 \\
\hline 19 & $0^{7}$ & 86 & $\mathrm{PH}$ & 1.5 & 9/14/1999 & 159 & 238 & 1,714 \\
\hline 20 & 우 & 86 & $\mathrm{PH}$ & 1.38 & $10 / 2 / 2001$ & 123 & 170 & 1,222 \\
\hline 21 & $0^{7}$ & 87 & PTE & 1.44 & $9 / 16 / 1998$ & 103 & 148 & 1,068 \\
\hline 22 & 우 & 90 & & 1.12 & $10 / 25 / 1996$ & 73 & 82 & 589 \\
\hline
\end{tabular}

$\overline{\mathrm{V} O} 2=$ flow of oxygen, $\mathrm{PTE}=$ pulmonary thromboembolism, $\mathrm{CHF}=$ chronic heart failure, $\mathrm{PH}=$ pulmonary hypertension. ? denotes suspicion of disease. 


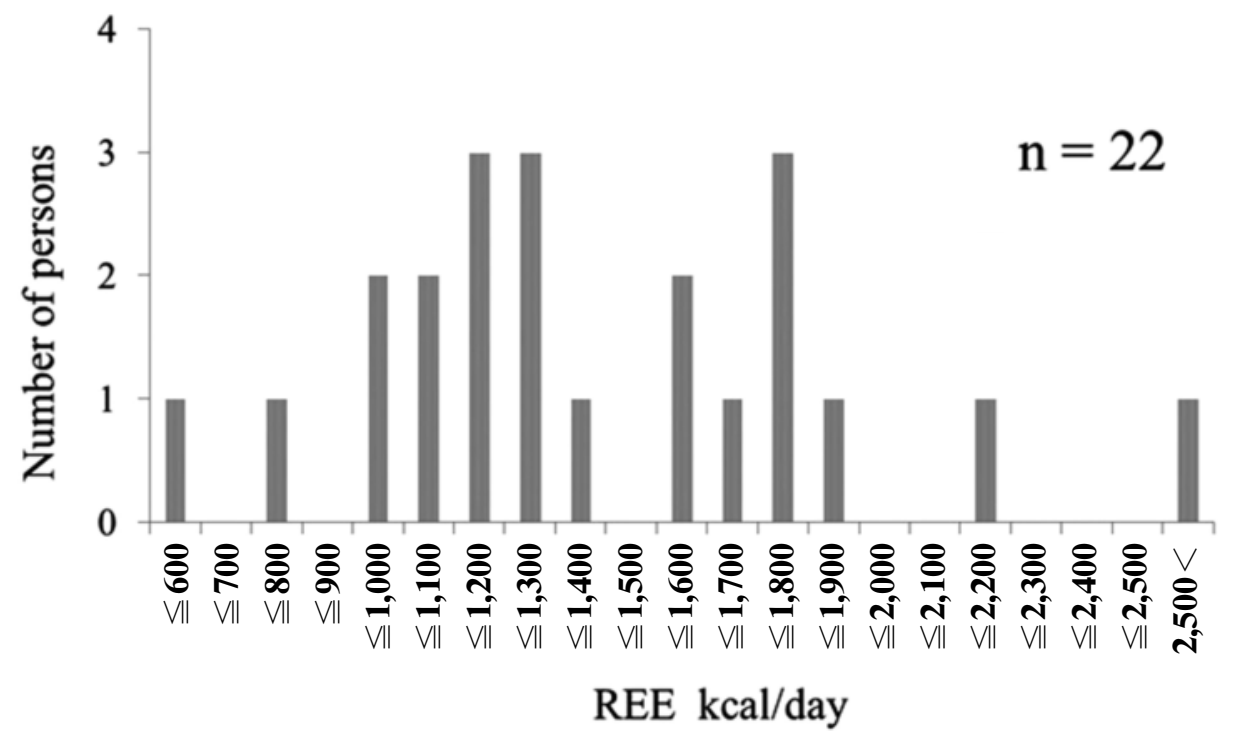

Figure 4 Frequency distribution of REE of the inpatients in the hospital who were $\geq 70$ years old and unhealthy, combined with the non-frail, frail, or disabled individuals.

resemble the distribution that was observed in Study 1 as shown in Figure 4.

\section{Discussion}

Hosoya et $\mathrm{al}^{11}$ previously reported on REEs of a total of 6,498 healthy individuals in Japan; these participants ranged in age from 1 to 104 years. The $\mathrm{REE} / \mathrm{kg}$ levels for the male and female subjects remained steady after the age of 15 years and were estimated to be approximately $29 \mathrm{kcal} / \mathrm{kg}$ for the male and female subjects. In addition, based on sex and age stratifications, these REEs showed a normal Gaussian distribution. They also showed that the mean value of REEs of the individuals who were older than 70 years was $1,665 \pm 437 \mathrm{kcal} / \mathrm{day} /$ body.

The present study demonstrated that the mean REE of the unhealthy elderly individuals in Study 1 was $909 \pm 239 \mathrm{kcal} / \mathrm{day} /$ body, which was $55 \%$ that of a healthy elderly individual, and was $21.6 \pm 4.5 \mathrm{kcal} /$ $\mathrm{kg} / \mathrm{day}$, which was $74 \%$ that of a healthy elderly individual, as described in the reports by Hosoya et al.

The individual actual EE could be obtained by calculating REE multiplied by the activity level. However, with low activity levels, Study 1 showed no correlation between REE of the elderly and the activity level during daily life in the population in the Roken. The degrees of the activity level was described in detail elsewhere. ${ }^{6,7}$ It means the value of REE would be near to the value of actual EE in the Roken. This may be due to the low activity level of the elderly in the Roken population.

As shown in Figure 3, discrepancies between REE and dietary energy intake without weight gain, even when the daily activity levels were considered, indicated that the absorptive factor of nutrition was more important than food intake.

In Study 2, REEs of the patients in the hospital, comprising a combination of non-frail, frail, and disabled subjects, were widely varied and did not show a normal Gaussian distribution. Therefore, the statistic comparison between Study 1 and Study 2 was not done. The reason of different distribution between study 1 and study 2 would be due to different population. Population of study 2 had included non-frailed elderly persons, otherwise population of study $1 \mathrm{did}$ not included non-frailed elderly persons.

The distribution pattern in Study 2 appeared to be a mixture of non-frail, frail, or disabled subjects; thus, there were two peaks that represented the unhealthy elderly described in Study 1 and non-frail healthy subjects which was similar to the findings described by Hosoya et al.

Based on the findings of the present study, we propose the following:

1. REE can be used as a surrogate marker for unhealthy elderly individuals who are frail or disabled.

2. Discrepancies between REE and dietary energy intake were observed and widely varied among the subjects. These findings suggested that although food intake through the alimentary therapy is important for the elderly, improving the effective absorption of nutrients from the digestive system is imperative.

3. We do not believe that low energy intake is sufficient for the elderly people with low energy expenditures because it is a well-known fact that malnutrition results in a decline in physical power, immunity, and vitality. Therefore, optimal effective dietary energy intake for the elderly with low energy expenditure should be established.

4. It appears to be essential to avoid excessive nutrition intake in comparison with REE, particularly in the elderly who are toward the end of their lifespans.

5. The design of an alimentary therapeutic strategy should be based on the individual measurements for 
REE of a patient, if possible.

\section{Acknowledgements}

The authors sincerely thank Yoshihiko Torii, who gave us the opportunity to measure REEs by using a portable indirect calorimeter (Metavine ${ }^{\circledR}$ ).

\section{Disclosure Statement}

There was no conflict of interest that has affected the results of this study. The institutional ethics committee approved this study.

\section{References}

1. Japan Association of Geriatric Health Services Facilities, editors. KAIGOHAKUSHO 2012 (White Paper 2012), Tokyo: KK Office TM, 2012; 202-205. (Available from: http://www.roken.or.jp/wp/english.Accessed April 4, 2015).

2. Health and Welfare Services for the Elderly. In: White Paper (Annual Report on Health and Welfare 1998-1999), Tokyo: Ministry of Health, labour and welfare, 1999; vol ume2, II-7. (Available from: http://www.mhlw.go.jp/english/ wp/wp-hw/vol2/p2c7.html. Accessed April 4, 2015).

3. Tabata I, Ebine N, Kawashima Y, et al. Dietary reference intakes for Japanese 2010: Energy. J Nutr Sci Vitaminol 2013; 59: S26-35.

4. Weijs PJ, Vansant GA. Validity of equation for resting energy expenditure in Belgian normal weight to morbid obese women. Clin Nutr 2010; 29: 347-351.

5. Tamura T, Ichinoseki N, Yoshimura T, et al. Development and evaluation of a simple calorimeter for the measurement of resting metabolism. Clin Exp Pharmacol Physiol Suppl 2002; 29: S2-6.

6. Amagai T, Mouri T, Ohkawa H, et al. Accuracy of flow and sensors of indirect calorimetry for neonates and infants: Using mass spectrometry and a pneumotachogram. Clin Exp Pharmacol Physiol Suppl 2002; 29: S7-8.

7. Kato M, Tajika M, Miwa Y, et al. Validation of a portable indirect calorimeter (Metavine ${ }^{\circledR}$ ) for measuring energy expenditure in an elderly population. Clin Exp Pharmacol Physiol Suppl 2002; 29: S9-12.

8. Igawa S, Sakamaki M, Miyazaki M. Examination of the reliability of the portable calorimeter. Clin Exp Pharmacol Physiol Suppl 2002; 29: S13-15.

9. Uza M, Tome K, Imai M, et al. A study of case finding of the latent bedridden elderly using criteria of activity of daily living. Minzoku Eisei, Japanese Journal Health and Human Ecology 1997; 63(2): 79-89. doi:http://dx.doi.org/10.3861/ jshhe.63.79

10. Sumii H, Ebara K. An investigation of the relationship between the kaigo index and the degree of independent living for the elderly and disabled. Bulletin of Hiroshima Prefectural College of Health and Welfare 1997; 3(1): 57-63 (in Japanese).

11. Hosoya N, Mitsuhashi F, Sugiyama M. Resting energy expenditure among Japanese. Clin Exp Pharmacol Physiol Suppl 2002; 29: S16-18. 